\title{
To the problem of the hermeneutics of the legal foundations of philosophy
}

\author{
Vitaly Kosykhin ${ }^{1 *}$, and Svetlana Malkina ${ }^{1}$ \\ ${ }^{1}$ Saratov State University, department of philosophy, 410012, Saratov, Russia
}

\begin{abstract}
In a certain sense, law and philosophy equally claim to be the fundamental basis of human activity. The present paper examines the problem of possible common field of interpretation for philosophical and legal hermeneutics, where a situation of mutual convergence could overcome a potential "conflict of interpretations". The interpretive nature of truth in hermeneutics reveals a multiplicity of possible foundations both in the principles of philosophy and in the concepts and norms of law. Hence, the main common task of philosophical and legal hermeneutics is the creation of a new sense of legality. The right is the establishment of some boundaries. But the philosophy is to put any boundaries and grounds in question, including the question of its own right. Therefore, the problem of legal philosophy inevitably leads us to questions about the right of philosophy and the right to philosophy.
\end{abstract}

\section{Introduction}

Perhaps no phenomenon of the classical and the modern world escapes the fate of being put into question in the era of postmodernity. It is natural that the space of questioning and thinking par excellence is itself put into question - namely, philosophy. The theme of the "overcoming of metaphysics" or the "end of philosophy" - whether it is discussed in the fundamental ontology of Heidegger or in analytic philosophy, - constantly occurs in the various areas of the nowadays philosophy. There are serious debates on and around this problem.

But if we suppose that someone can give to philosophy the right to life, does it mean that he can also give it a basis? Philosophy, after all, itself makes ultimate foundations, so it is impossible to set the legal field of philosophy, as it can be done with other phenomena. If this could mean the fundamental lack of rights of philosophy then we would only examine the legal foundations of philosophy as a datum. Here, in our opinion, there are three possibilities.

\footnotetext{
${ }^{*}$ Corresponding author: Kosyhinvg@gmail.com
} 
Firstly, we can outline the sphere of theses or defining practices that are attributable to the very nature of "philosophy", thus creating the program, which would become the legal basis for the organization of a circle of researchers.

Secondly, philosophy can constitute itself not through a kind of argumentative identity, but through the range of questions that do not provide general answers, but set forth some plan of immanence, the horizon of thinking. It is also a kind of legal field in which we follow not to the letter of the law, as in the first case, but to its spirit. In a certain sense, talking about philosophy in general, we deal with the following situation: there are no definitions that were given directly or implicitly to the nature of philosophy that could be shared by the whole philosophical community. But, perhaps, there was no philosopher for whom the question of the essence of philosophy would meaningless for his philosophizing, being constitutive for his and his followers' thought-space.

Thirdly, any philosophical project can be organized nor through any particular question or any particular answer to it, but through some intercommunity of the experience of thinking. The question when being asked, is guiding us along the certain path, even if it does not imply the concrete answer. Here we turn to the interrogative situation itself, in this case - to the interrogative situation of the relationship of law and philosophy [1, p.194].

\section{The problem of the dialogue of philosophical and legal hermeneutics}

How big is the distance between philosophical and legal interpretations and whether it is proper to pose the existence of a common field of interpretation for both philosophical and legal hermeneutics? Can we today think that the scientific fields of philosophy and law are in the situation of mutual convergence, overcoming the potential "conflict of interpretations"?

This problem is traditionally considered in modern philosophy within the frameworks of its hermeneutically oriented thought and to better clarify the current state of the question is quite logical to investigate the positions of the leading representatives of philosophical hermeneutics as are Hans-Georg Gadamer and Gianni Vattimo.

Due to the works of Dilthey, it had become a common belief that only in the field of history hermeneutics could be the universal method of objective science dealing with the interpretation and understanding of the text. With this approach, legal hermeneutics becomes a particular science which does not investigate the understanding as such. It is aimed not so much to understand the text, as it was, but to correct "misunderstandings" in the legal system as a dogmatic system. So it turns out that this essentially dogmatic position prevents legal hermeneutics to reach the level of general methods of contemporary humanities.

Then what is the difference between the approaches of historical (general) and legal hermeneutics? From Gadamer's point of view, «the jurist understands the meaning of the law from the present case and for the sake of this present case. By contrast, the legal historian has no case from which to start, but he seeks to determine the meaning of the law by constructing the whole range of its applications. It is only in all its applications that the law becomes concrete. Thus the legal historian cannot be content to take the original application of the law as determining its original meaning. As a historian he will, rather, have to take account of the historical change that the law has undergone» [2, p. 322]. 
However, despite the apparent difference in the tasks of a historian of law and a jurist to identify the original meaning of the law or to correlate it with the legal modernity - in practice these tasks are complementary to each other.

For a long time, legal scholars recognized the uniqueness of the legal meaning of a law, arguing that the practice of law tends to follow that sense. But in this case the areas of historical and legal hermeneutics would coincide. Then the problem would be to establish the single original meaning of the law and its application in that capacity. This position, according to Gadamer, necessarily ignores the difference between the original and the modern meanings of a law. But over time, this discrepancy became apparent to legal hermeneutics, which led it to the recognition of the need to correlate these meanings.

A historian of law, on the surface, is only interested in the original meaning of law, in its legal significance in the period of enactment. But to know that original meaning, it is necessary to understand the changes that separate the era of the law enactment from modernity. It turns out that direct knowledge of the historical meaning of a law, as well as of its legal sense, is impossible and a historian of law have to do the same hermeneutic work as a jurist. Both, a historical and a legal knowledge can be carried out only through the examination of the past in its relationship with the present.

However, the practical orientation in the interpretation of law requires the knowledge of its legal meaning. As the subject of understanding, text takes on its semantic completeness only in the process of interpretation, which reveals the additional and hidden meanings in the body of text. Legal hermeneutics is necessary, because only through the procedure of understanding the explication of meaning occurs, and a jurist often forced to act during the interpretation of law as a historian and as a scholar philologist at the same time. Thus, according to Gadamer, we can no longer talk about legal hermeneutics as a particular science, as it reaches the methodological level of general hermeneutics.

Thus in his hermeneutic activity a lawyer is not just applying the general principle of interpretation to a specific case, the principle which would be the original and understandable by itself, but its application itself is just a genuine understanding of the universal meaning, which is revealed to us through the text [3, p.45]..

Nowadays, active discussion on the conditions of a dialogue between the two hermeneutics, philosophical and legal, is carried out in hermeneutical philosophy of Gianni Vattimo. The unifying concept here, according to Vattimo, is the notion of interpretation: «The role of interpretation and its conditions in the administration of justice has become more visible because in a democratic society the relationship among the powers may indeed be tendentially regulated by ironbound laws, but it is also made so explicit by these very laws that the activity of the courts and other jurisdictional forums is rendered less "sacral" and their aura stripped away. For another thing, the increasing complexity of state forms has enormously accentuated the distance between the law and justice. Juridical formalism does not, in practice, really appear to be taking account of the "reality" of facts, the truth of the "rights" claimed by individuals and groups, of new rights, those, for example, demanded by the "new subjects" who are pressing for recognition in everyday life» » [4, p. 143].

Procedural mechanisms, rotating slowly, induce retaliatory non-tolerance in the society that is no longer limited by the sacred aura of law, the non-tolerance which is caused by a thirst for justice. Here the conflict of interpretations between justice and law starts.

Modernity, which Vattimo calls nihilistic, is characterized, in his terms, by the philosophy of "the weakening of the power of thought", i.e. by the increasing role of interpretation as opposed to the substantiality of the classical systematic thinking in philosophy and law. The distinction between "strong" and "weak" thinking, pensiero forte 
and pensiero debole, Vattimo sees in close relation to the interpretation, which tends to aim either the intrinsic uniqueness in the first case, or the conventionalism of multiplicity of possible interpretations in the second.

Vattimo links this turn to the complication of interpretive procedures with the strengthening of the democratic institutions of society.

The question of the change and transformation of the rules of the game is essential to modern thought in general, both legal and philosophical. It means entering the situation of permanent hermeneutic efforts to find more and more reasons for the current mode of interpretation, the efforts that will never end, but are always renewed. This position is particularly true for new hermeneutical strategies of postmodernism and deconstruction, whose influence on the Vattimo's hermeneutical approach seems to be very significant. The practice of modern law-making and low-enforcement processes in general also focuses on the dialogue of interpretations of low; it never reaches its final hermeneutical results and therefore it is open for any urgent changes.

Criticism of any sociological dominance in philosophy is, according to Vattimo, the main task of contemporary hermeneutic thinking, founding itself in opposition to the new social and legal nihilism of postmodernity, when everything is dissolving not in the values, but in the demands of the moment and the social problematic.

For Vattimo (perhaps in this point he is also affected by the lessons of Nietzsche and Heidegger) hermeneutics starts from the position that Being itself is inseparable from its interpretation. In this case, we engage in a hermeneutic circle of interpretative interconnections and interdependencies, since, as it is noted by Santiago Zabala, «understanding the "circularity" of interpretation is essential to understanding our postmodern approach not only toward modernity but also toward traditional metaphysical onto-theology, because if every interpretation is itself based on a different interpretation, then the circle of interpretation cannot be escaped or overcome completely» [5, p. 16].

\section{Right to Philosophy}

Being in the legal field we have to do in the first turn with philosophy as an institution and that allows us to talk about philosophy in terms of law [6, p.184]. The question of the right - these are the problems of contract, property, freedom and responsibility. And in all of them we meet with some philosophical "must" that lies at their base.

This demand we meet from the beginning of philosophy. When Heraclitus says, "We need to follow the universal" what is the nature of this "need"? And does here take place the coercion, external or internal, can we not to follow this universal? The need can be different: one thing is the unconditional need of a priori judgments (but there is no need here to point to it by the additional "must"), but there is another need of natural laws ("arrangement of the world"), there is also conditional and goal-setting need ("hypothetical"), and there is a moral necessity .... So what is the nature of the philosophical "must"? In a certain sense, it is the synthesis of all the forms of need, but in the first turn - it is the necessity, coming from the very meaning of the "universal". The nature of Heraclitean logos lies in the fact that it is also our nature we do not know. Therefore, for the one who sees this nature, no coercion is assumed: how can you give up your own foundation? And the paradox feature of this "need" is that it simultaneously reveals freedom to a man, not freedom of choice but freedom of breaking the horizon, when the matter of thinking is not this or that, but the universal. Therefore, it is not just a moral need, when exactly a man decides how to act, here a man discovers in himself not the 
sphere of subjectivity but, on the contrary, the sphere of objectivity (It is not accidentally that for Hegel the right is disclosure of the objectivity of the spirit). This is an unconditional demand that, once heard, leaves no alternatives.

Thus, the philosophical exactingness opens for us at the same time the horizon of the problem of property. To consider the question of philosophical property let's turn to the two famous philosophical interpretations of property: Hegelian (Eigentum) and Heideggerian (Eigentlichkeit). For Hegel, «by the judgment of possession, at first in the outward appropriation, the thing acquires the predicate of "mine". But this predicate, on its own account merely "practical", has here the signification that I put my personal will into the thing» $[7$, p. 220].

For Heidegger, the "proper", the "authentic" designates the realization of the mode of Being that is unique or "its own", Dasein. Here he clearly speaks not about imposing the will on things, but rather, on the contrary, about accordance with Being, which reveals the possibility of a genuine and non-genuine to a man. This beings, i.e. Dasein «can, in its very Being, 'choose' itself and win itself; it can also lose itself and never win itself; or only 'seem' to do so. But only in so far as it is essentially something which can be authentic-that is, something of its own - can it have lost itself and not yet won itself» [8, p. 68].

The property of philosophy is a matter of thinking, but what does it consist of - state of legal dispute, of inquiry. This brings to mind the "fateful debt", which, according to Anaximander, was the logic of Being and caused things to be in the permanent dispute with each other. As to the proper philosophy, this inquiry is not just a dispute because for the philosophy its speech is always about the grounds and, first of all, of its own grounds. That is why the legal space of philosophy, its right is the investigation of its proper grounds, court litigation on the case of thinking.

But the question on the right to philosophy can be put in the sense of "human rights". Why do we put such a question at all? When it comes to the right to life or the right to freedom as the natural rights, it implies that there is a discourse, the institution, the practice of denying the "naturalness" of the right. Then can we treat the "right to philosophy" as the natural, fundamental right, and is there a discriminatory discourse that deprives someone of such right?

Internal discrimination is associated with the space of philosophy itself. There has always been and continues to be today a competition of national schools and traditions in philosophy. For example, clear demarcation between the Anglo-Saxon empirical analytic tradition and the continental French and German schools (where, however, there are also separate confrontations) seems actual for modern philosophy. This adherence of philosophy to this or that tradition implies at the same time the adherence to a particular philosophical language that directs our thought in definite direction. Hence, the question of how to understand the universality of the right to philosophy - not to philosophy, claimed by different school in the particular languages, but to the abilities of overcoming these limits, tearing philosophy of language into a series of separate language practices, arises.

Thus, the language becomes an unavoidable mediator, requiring specific treatment strategies to solve the question on the right to philosophy.

Unlimited right to philosophy should mean overcoming of the limitations imposed by the language, but it can be done only through the pluralism of linguistic traditions, to overcome their hegemony.

\section{Conclusion}


We suppose that the justification of the right to philosophy does not mean mastering of all the particular traditions and languages, it rather, on the contrary, means the deconstruction of all the forms of the concept of "proper", thus getting rid of dogmatism and philosophical snobbery. Thereby philosophy doesn't reject the proper; it rather should go beyond the opposition between the proper and the expropriated.

But we'll not understand this argument correctly without revealing the paradox relating to the heritage of tradition. If we talk about the heritage of a tradition it is necessary to respond to that heritage. And here again we find ourselves in the sphere of law, when we talk about philosophy as a kind of a responsibility to the tradition and, at the same time, responsibility to ourselves. Paul Valéry in his "Freedom of the mind" spoke of a culture as a capital, which may increase or decrease depending on the reproduction of the relevant practices (such as growth of capital through investments). Similarly, Derrida speaks of the need for "a responsible memory", which is realized through repetition, but not as a simple replay, as it was. that can be interpreted as "invested" with a profit (so there is an aporia, but not a contradiction between memory and something "completely new") [9, p.18].

In this case, we are realizing our right to the inheritance, which is given to us only under certain conditions (by observing that, we get access to the heritage). Only such an implementation has all the rights, as human rights are not an entity, they are only given in the implementation, "incompletely", they are always have to be re-assert. All the rights (including the right to philosophy) assert themselves on the border of human rights in the name of the ideal of law.

\section{References}

1. A. Dronov, V. Kosykhin, Horizon, Fenomenologiceskie Issledovania, 2, 188-195 (2013).

2. H-G Gadamer, Truth and method (New-York: Continuum, London, 2004).

3. B.I. Pruzhinin and al., Communications in science: Epistemological, socio-cultural and infrastructural aspects. Materials of the Round Table, Voprosy Filosofii, 11, 23-57 (2017).

4. G. Vattimo, Nihilism and Emancipation: Ethics, Politics and Law (Columbia University Press, New York, 2006)

5. S. Zabala, "Introduction: Gianni Vattimo and Weak Philosophy.", Weakening Philosophy: Essays in Honour of Gianni Vattimo, 3-34 (McGill-Queen's University Press, Montreal, 2007).

6. V.P. Rozhkov, S.M. Malkina, Dedicated to the anniversary to the Russian Philosophical Society, Voprosy Filosofii, 10, 183-188 (2006).

7. Hegel, Georg Wilhelm Friedrich, Philosophy of Mind (Clarendon Press, Oxford, 2010).

8. Martin Heidegger, Being and time (Blackwell, Oxford UK \& Cambridge USA, 2001).

9. Derrida Jaques, Who's afraid of philosophy?, Right to Philosophy I. Stanford (Stanford University Press, CA, 2002). 